\title{
Application of field studies and geostatistical methods in assessment of odour nuisance based on selected examples from municipal, industrial and agricultural environments ${ }^{1}$
}

\section{Zastosowanie badań terenowych oraz metod geostatystycznych w ocenie uciążliwości zapachowej na przykładzie wybranych obiektów z zakresu gospodarki komunalnej, przemysłowej oraz rolnej}

\begin{abstract}
* Dr hab. inż. Izabela Sówka, prof. nadzw., mgr inż. Łukasz Pachurka, mgr inż. Yarosław Bezyk, mgr inż. Agnieszka Grzelka, mgr inż. Urszula Miller - Unit of Ecologistics and Environmental Risk Management, Faculty of Environmental Engineering, Wroclaw University of Science and Technology, PI. Grunwaldzki 9, 50-377 Wrocław, tel. 0048713202560 , e-mail: izabela.sowka@pwr.edu.pl
\end{abstract}

Keywords: odours, field measurements, GIS

Słowa kluczowe: odory, badania terenowe, GIS

\section{Abstract}

In Europe and around the world, field studies conducted in areas surrounding the odour source are used for evaluating the odour nuisance and for emission studies. In Europe, the Standards of the Association of German Engineers (VDI) - VDI 3940 series for grid and odour-plume measurements are used. Carrying out this type of research allows for the assessment of olfactory air quality in a 'quantitative' analysis by characterizing a particular odour in terms of its impact and its frequency. In addition, in order to analyse and visualize the distribution of odours occurring in a certain area, by using the results of field studies, the Geographical Information System (GIS) tools may be applied. The research methodology, including the results of field measurements and geostatistical analysis in the assessment of odour nuisance, could be very important tools for the determination and spatial interpolation of odour intensity distributions and studying the range of odorous plumes. This paper presents the results of field measurements and geostatistical analysis conducted for selected municipal, industrial and agricultural sectors objects.

\section{() IOŚ-PIB}

\section{INTRODUCTION}

The odour nuisance in Europe and in the developed world countries are regulated by law, and therefore classified as an environmental pollution. The negative effects of odours are, for example, the deterioration of natural environment, discomfort, deterioration in the quality of life and safety, damage to human life, plants and property, as well as disruption of normal business activities and property use. Odour pollution of air is defined by the discomfort caused by substances or associated conditions that may adversely affect a single person or group of people. Such pollution usually results in discomfort perception. The negative

${ }^{1}$ This work was supported by a statutory research No. 0401/0065/16.

\section{Streszczenie}

W Europie i na świecie do oceny uciążliwości zapachowej oraz badań imisyjnych na obszarach znajdujących się wokół badanego obiektu znajdują m.in. zastosowanie badania terenowe. W Europie stosuje się m.in. normy Stowarzyszenia Inżynierów Niemieckich (VDI) serii VDI 3940 stosowane do pomiarów w siatce oraz w smudze. Przeprowadzenie tego typu badań pozwala uzyskać ocenę jakości zapachowej w sposób „ilościowy” poprzez scharakteryzowanie określonego zapachu pod względem jego oddziaływania i jego częstości. Dodatkowo, w celu analizy oraz wizualizacji rozkładu występujących na badanym obszarze zapachów, wykorzystując wyniki badań terenowych, można zastosować narzędzia GIS (System Informacji Geograficznej). Proponowane metody pomiarów terenowych i analiz geostatystycznych w ocenie uciążliwości zapachowej są bardzo istotnymi narzędziami do identyfikacji rozkładów przestrzennych intensywności zapachów i interpolacji oraz badania zasięgu smugi odorowej. W pracy przedstawiono wyniki pomiarów terenowych oraz analiz geostatystycznych przeprowadzonych dla wybranych obiektów gospodarki komunalnej (zakład gospodarowania odpadami), przemysłowej (zakład przeróbki tworzyw sztucznych) oraz hodowlanej (ferma świń).

impact of odour is usually derived from subjective perception and has a destructive impact on the human psyche (Rutkowski et all 1995), (VDI 3883 P. 1 1997), (Zwoździak et all 2006), (Vance 2008), (The draft: Law on the prevention of odour nuisance, 2009); (Sówka 2011). The perception of odour pollution of air is influenced by several factors, which could reduce or increase the perception of a particular person for a particular aroma. In addition to the factors affecting the olfactory perception of odour, other external factors may play a role as well. Certain external factors include: non-odour factors (vibration, noise, air pollution by particulate matter); spatial planning and the environmental conditions (architecture, the structure of socio-economic 
situation, the current level of odours); situations associated with high odour concentrations (sleep duration, length of time in an odorous environment, fatigue, housing situation) (VDI 3883 P. 1 1997), (Sówka et al. 2010).

Odours can cause different reactions in humans, including irritation as well as documented health effects. Through prolonged exposure to odours, some people may experience adverse reactions, for example, vomiting, nausea, respiratory problems, anxiety, headache and mental tension associated with insomnia and lack of appetite (Nicell 2009). Due to the negative impact of odour, it is important to regulate the legal system and to propose the optimal methodology for odour measurements in areas located near the odour emission sources in relation to municipal, agricultural and industrial sectors.

\section{FIELD STUDIES}

The method of odour concentration measurements in the gases emitted in the air is described in the European standard EN 13725 : 2003, amended in 2006. The Polish PN-EN 13725: 2005 standard has been replaced by PL EN 13725: 2007 (PN-EN1375:2007 2007), (Sówka et all. 2010). In contrast, the assessments of odour nuisance and emission research are studied using the Association of German Engineers (VDI) standards. VDI 3940 series are used for measurements in the grid and in the plume (VDI 3940 P. 1 2006), (VDI 3940 P. 2 2006), (VDI 3940 P. 3 2008), (Sówka et al. 2010), (Sówka 2011).

\subsection{Grid measurements}

The guidelines define measurements in the grid as a statistical method of measurement, where in the course of a predetermined time period, for example, 6 months, a team of evaluators records the identified odours on a measurement grid encompassing a predetermined area according to a specified methodology. The results are then used to calculate the characteristic of odour impact (number of hours the odour impacts during the yearodour hours) in the sub-fields in the area of study. Measurements in the grid allow for a determination of the existing levels of odour caused by sources, both inside and outside the grid (VDI 3940 P. 1 2006).

According to the VDI, the proposed study area is a circle with its centre as the odour origin. In case of many odour sources, the centre of the odour generating plant is selected, with the radius being at least 30 times the height of the odour emitter. In the case of low odour sources $(<20 \mathrm{~m})$, the study area should be determined at the shortest distance from the odour generating plant to the area boundary - at least 600 m (VDI 3940 P. 12006 ) The measurement cycle consists of a single measurement at the measurement point, in case of field research, this being equal to a time of 10 minutes. An odour emission study is organized by an experienced operator supervising a team of evaluators. An important initial step is to draw up a research plan and record the results. The operator is also responsible for handling the measurement instruments used in the study, and ensuring that the odour intensity scale and type codes are well understood by the evaluating team. Immediately after gathering all the protocols of the evaluation, the operator should check all the data for completeness and reliability (VDI 3940 P. 1 2006). The criteria for selection of the evaluating team is sensitivity to n-butanol, a standard reference substance. This criterion provides for compatibility with odour sensitivity of the evaluators, as tested during the olfactory measurement, per methodology specified in PN-EN 13275 (VDI 3940 P. 1 2006), (PN-EN 13725:2007 2007). Before starting the research, the team of evaluators should be trained by the operator with regard to the odour codes and intensity scale used in the study. Each assessor should be able to identify the smells during reconnaissance in the vicinity of the plant/factory. The evaluators assign their individual impression of odour to one term of the scale depicted, in accordance with VDI 3882 (Sówka 2011), (VDI 3882 P. 2 1994).

\subsection{In-Plume measurements}

Odour nuisance measurements in a plume are described in the second part of the VDI 3940 (VDI 3940 P. 2 2006). In odourplume measurements are conducted to gather information as to the impact of the odour within the plume effective area. Such a study takes place in certain weather conditions, due to the dependence of odour plumes coming from a given emitter on wind speed and direction, as well as the atmospheric equilibrium conditions prevailing over the given area. During the study, factors such as fog, snow or rain should also be taken into account (VDI 3940 P. 2 2006). The odour-plume measurements consist of 10 minute measurements at the intersections of lines at specific angles at appropriate angles to the wind. The end of the plume is determined as a percentage of the presence of the tested odour, which is equal to $10 \%$ of the measurement cycle. Measurement consists of at least five evaluators at five evaluation points. As in the case of measurements in the grid, the percentage of time an odour is present during a single measurement is used as a variable in calculating the odour impact (VDI 3940 P. 2 2006), (Sówka et al. 2010), (Sówka 2011).

\section{THE EXAMPLES OF USE OF FIELD RESEARCH IN THE ASSESSMENT OF ODOUR NUISANCE}

Field measurements can be used in the assessment of odour pollution of air and the olfactory impact of different types of objects including landfills and waste treatment plants, as well as industrial plants and animal facilities (Sówka et al. 2013). An example of the possibilities of using field studies for evaluating the olfactory impact of different facilities are the measurements around municipal waste management (Plant I and Plant II), industrial (Plant III) and animal (Plant IV) plants (Table 1).

For the two municipal waste management plants (Plant I and Plant II), the measurements were conducted in 'measurement plumes' where the measurement points were approximately 50 or 100 meters apart. During the evaluation, each member of the group of researchers assessed the intensity of the perceived odour on a scale of 0 to 6 , where 0 indicates no odour, 1 - very weak odour, 2 - weak odour, 3 - distinct odour, 4 - strong odour, 5 - very strong odour and 6 - extremely strong odour. Furthermore, on the basis 
of a field reconnaissance, the odours were characterized as: $A-$ no odour, B - composting, C - chemical - sweet from deodorization, D - municipal waste, E - green waste, $F$ - construction waste, $G$ car exhaust gases, $\mathrm{H}$ - home furnaces, and I- other.

In case of Plant III (industry object), the measurements were conducted in the surroundings of the plant in a previously determined grid. The assessment group characterized the perceived odour in intensity according to the same scale as in the case of Plants I and II, while the nature of the odour was determined in the form of the following codes: A - no odour, B - chemical odour, C - the odour of plastic, D - a sweet odour, E - the odour of car exhaust gases, F - the odour of grass, G- the odour of trees, $\mathrm{H}$ - the odour of animal manure/waste, I - the odour of animals, $\mathrm{J}$ - the odour of household waste, $\mathrm{K}$ - other. Plant IV, is an example of an animal facility (pig farm). The intensity of the perceived odour was assessed according to the scale described above and for the purpose of determining the nature of the perceived odour, the following codes were utilized: A- no odour, B - agricultural odour, C - agricultural odour: pig farming, D - agricultural odour: cow farming, E - agricultural odour: horse farming, F - agricultural odour: straw, grain, G - the odour of car exhaust fumes, $\mathrm{H}$ - the odour of coal burning, I - the odour of grass, $\mathrm{J}$ - other: specify L - manure, P - rotten meat, R utilization 1 , and $S$ - 2 utilization.

The results of the studies were used to prepare the statistics concerning the frequency of each odour type frequency found at each measurement site (Table 1) and the frequency of each odour intensity (Table 2) for a given day at a measurement site.

\section{GEOSTATISTICAL METHODS IN THE EVALUATION OF ODOUR AIR QUALITY}

The application of Geographical Information Systems is the one of the most promising area for spatial analysis with regard to odour emitting objects. The use of GIS tools for spatial analysis of olfactory impact around municipal waste treatment, industrial and agricultural objects allows for an evaluation of the assessment of odour nuisance phenomenon occurrence. GIS allows for an optimal visualization of input data (in the case of field studies, e.g., control measurement points) in order to estimate the parameters of odour air quality around a studied object and its impact on the environment. It also allows for a quantitative description of the model quality through statistical error analysis of the interpolated surface. On the figures 1 and 2, the example results of implementing GIS for odour pollution of air (using the GIS tool pack GIS ArcMap 10.3.1) are shown.

Figure 1 shows the results of constructing a research zone (field study area) of a size of $2.3 \times 1.9 \mathrm{~km}$, where the measurement points were placed along the streets in areas surrounding a municipal waste treatment plant (Plant I). As shown in figure 1 , the spatial data is presented as points (discrete data) that are distributed in the 'measurement plume'. The odour plume included 70 points, which were disposed from each other at distances of approx. 50 and $100 \mathrm{~m}$. The measurement data was given as symbols according to the intensity values, that is from 0 to 6 . The size of each symbol indicates the frequency of presence of intensity.

Figure 2 shows the example of exploring data results obtained for a selected type of odour: 'B - composting', very specific for Plant I. To predict the unknown values of odour intensity and its spatial distribution, a geostatistical interpolation technique - kriging was used. The data exploration was performed for the maximum intensity parameter. The calculation results were verified based on an error analysis through a cross-type validation (model accuracy evaluation) (Werner 2004). Cross-validation, absolute error and mean squared error were applied to obtain the best values of geostatistical interpolation model (table 3). These variables (standard errors), as one of the outputs of kriging, are very useful for the improvement of the estimated and observed values.

Table 1. The frequency of odour type in the research area on the day of measurement for waste management (Plant I and Plant II), industrial (Plant III) and animal facilities (Plant IV).

\begin{tabular}{|c|c|c|c|c|c|c|c|c|c|c|c|c|c|}
\hline \multicolumn{14}{|l|}{ Plant I } \\
\hline Type of odour & \multicolumn{2}{|c|}{ A } & B & \multicolumn{2}{|c|}{ C } & \multicolumn{2}{|l|}{ D } & E & \multicolumn{2}{|c|}{$\mathrm{F}$} & G & $\mathrm{H}$ & I \\
\hline $\begin{array}{l}\text { Frequency of } \\
\text { occurrence, \% }\end{array}$ & \multicolumn{2}{|c|}{57.22} & 0.56 & \multicolumn{2}{|c|}{5.00} & \multicolumn{2}{|c|}{10.91} & 0.63 & \multicolumn{2}{|c|}{0.00} & 5.40 & 8.41 & 11.87 \\
\hline \multicolumn{14}{|l|}{ Plant II } \\
\hline Type of odour & \multicolumn{2}{|c|}{ A } & B & \multicolumn{2}{|c|}{ C } & \multicolumn{2}{|l|}{ D } & E & \multicolumn{2}{|c|}{$\mathrm{F}$} & G & $\mathrm{H}$ & I \\
\hline $\begin{array}{l}\text { Frequency of } \\
\text { occurrence, \% }\end{array}$ & \multicolumn{2}{|c|}{57.40} & 10.98 & \multicolumn{2}{|c|}{0.00} & \multicolumn{2}{|c|}{10.39} & 2.06 & 0.10 & \multicolumn{2}{|c|}{13.33} & 4.31 & 1.42 \\
\hline \multicolumn{14}{|l|}{ Plant III } \\
\hline Type of odour & \multicolumn{2}{|l|}{ A } & B & C & D & \multicolumn{2}{|c|}{$E$} & $\mathrm{~F}$ & G & $\mathrm{H}$ & 1 & $J$ & K \\
\hline $\begin{array}{l}\text { Frequency of } \\
\text { occurrence, \% }\end{array}$ & \multicolumn{2}{|c|}{42.24} & 3.68 & 6.05 & 0.35 & & & 19.61 & 16.35 & 0.00 & 0.09 & 0.48 & 5.44 \\
\hline Plant IV & & & & & & & & & & & & & \\
\hline Type of odour & A & B & C & D & $E$ & $F$ & G & $\mathrm{H}$ & 1 & $J$ & L & $P$ & $\mathrm{R}$ \\
\hline $\begin{array}{l}\text { Frequency of } \\
\text { occurrence, \% }\end{array}$ & 8.56 & 0.00 & 13.90 & 0.00 & 0.00 & 0.12 & 0.00 & 0.29 & 1.45 & 0.00 & 68.69 & 3.06 & 3.93 \\
\hline
\end{tabular}




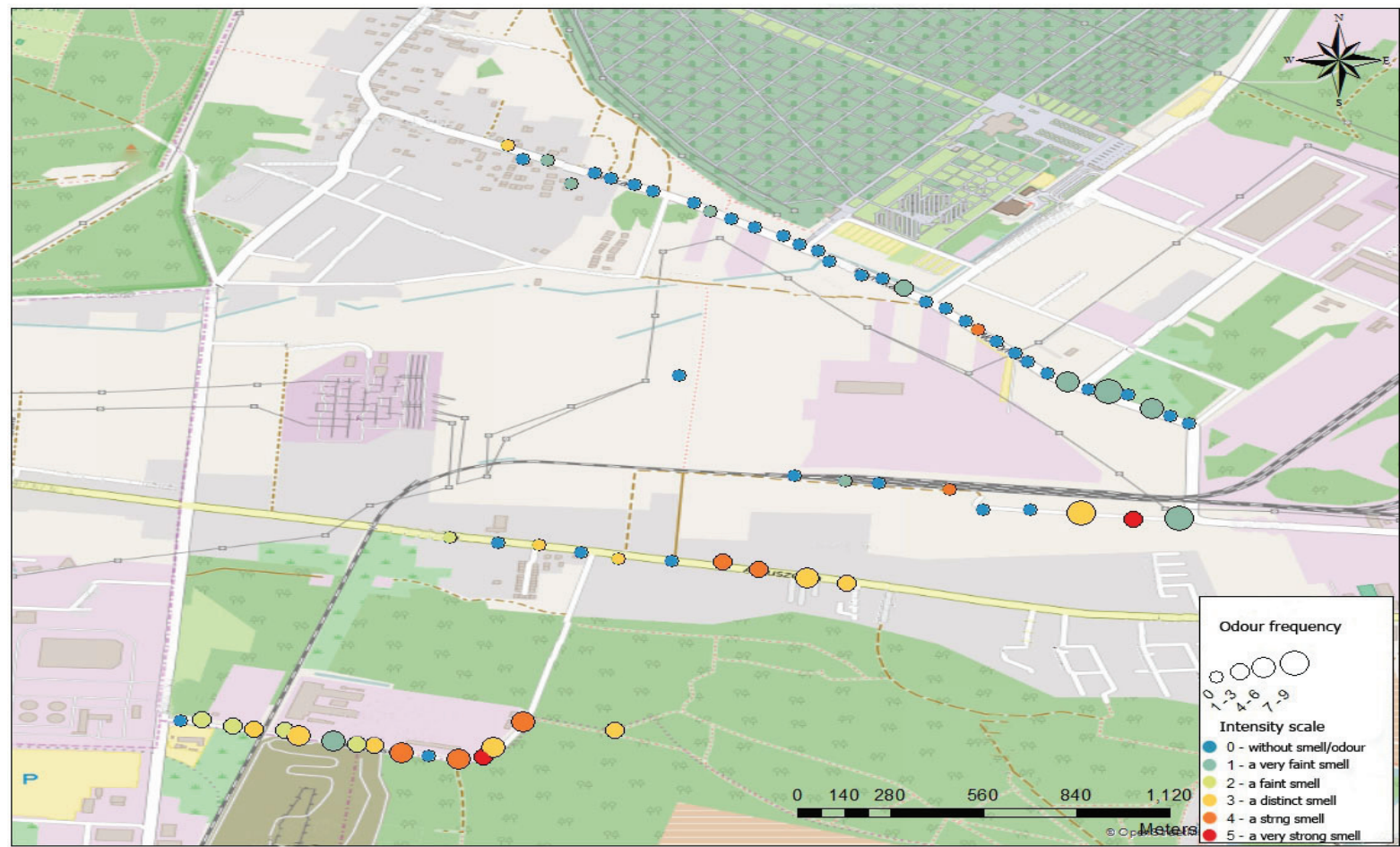

Figure 1. Example of measurement points distribution concerning the maximum intensity values for a given odour type: 'B' ('composting') for Plant I (base map source: OpenStreetMap - (C) OpenStreetMap (and) contributors, CC-BY-SA).

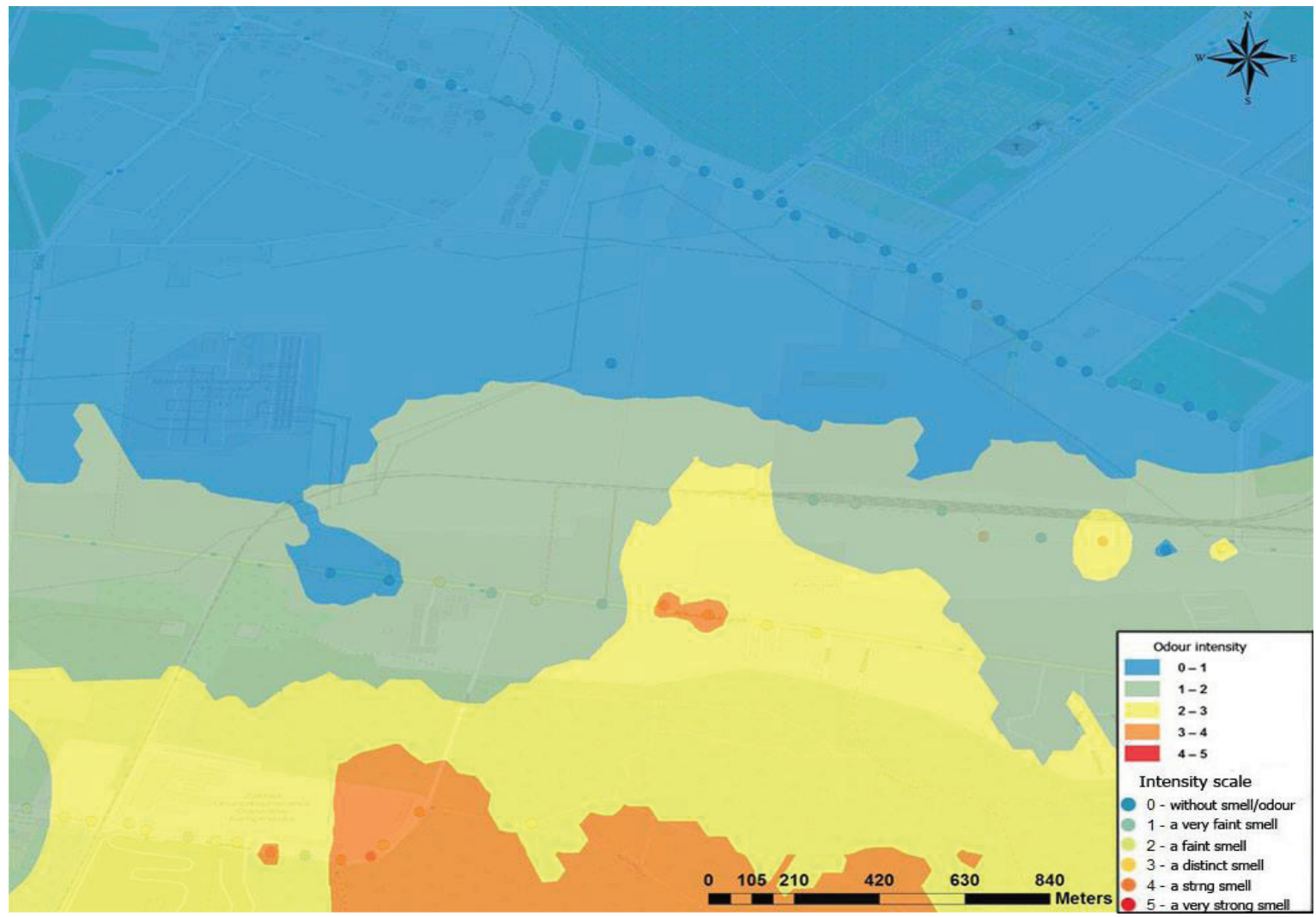

Figure 2. Calculated spatial distribution of the intensity of the chosen odour type: 'B' (composting) and maximum intensity values in the measurement plume for Plant I (base map source: OpenStreetMap - (c) OpenStreetMap (and) contributors, CC-BY-SA). 
Table 2. The frequency of odour intensity on the day of measurement for waste management (Plant I and Plant II), industrial (Plant III) and animal facilities (Plant IV).

\begin{tabular}{|c|c|c|c|c|c|c|}
\hline \multicolumn{7}{|l|}{ Plant I } \\
\hline Odour intensity & 0 & 1 & 2 & 3 & 4 & 5 \\
\hline Frequency of occurrence, $\%$ & 57.09 & 14.61 & 13.10 & 8.93 & 4.68 & 1.27 \\
\hline \multicolumn{7}{|l|}{ Plant II } \\
\hline Odour intensity & 0 & 1 & 2 & 3 & 4 & 5 \\
\hline Frequency of occurrence, $\%$ & 57.40 & 14.95 & 11.13 & 5.20 & 4.07 & 2.70 \\
\hline \multicolumn{7}{|l|}{ Plant III } \\
\hline Odour intensity & 0 & 1 & 2 & 3 & 4 & 5 \\
\hline Frequency of occurrence, $\%$ & 87.15 & 7.06 & 3.46 & 1.97 & 0.31 & 0.04 \\
\hline \multicolumn{7}{|l|}{ Plant IV } \\
\hline Odour intensity & 0 & 1 & 2 & 3 & 4 & 5 \\
\hline Frequency of occurrence, $\%$ & 8.56 & 12.69 & 30.69 & 33.54 & 8.48 & 4.80 \\
\hline
\end{tabular}

Table 3. Variants of kriging interpolation and errors calculated based on the cross-validation.

\begin{tabular}{|c|c|c|c|c|c|}
\hline Data & Sample size & $\begin{array}{c}\text { The value of the optimum } \\
\text { power factor }\end{array}$ & $\begin{array}{c}\text { Neighbour points to } \\
\text { include }\end{array}$ & $\begin{array}{c}\text { Standard } \\
\text { error }\end{array}$ & $\begin{array}{c}\text { Mean squared } \\
\text { error }\end{array}$ \\
\hline Seria I.1 & 70 & 2 & 10 & 0.0146 & 1.508 \\
\hline Seria I.2 & 40 & 2 & 6 & 0.059 & 0.674 \\
\hline Seria II.1 & 42 & 1.9 & 8 & -0.070 & 1.628 \\
\hline Seria II.2 & 34 & 1.95 & 6 & -0.047 & 1.638 \\
\hline Seria III.1 & 42 & 2 & 8 & 0.122 & 1.214 \\
\hline Seria III.2 & 22 & 1.9 & 8 & 0.049 & 1.431 \\
\hline
\end{tabular}

The performed analysis indicated that the described characteristic allows for an identification of areas (e.g., specific streets, buildings) which are characterized by the presence of highest intensity values (indicated by the residents as the 'hardest ') of the odour emitted from the studied plant.

\section{CONCLUSION}

The use of field studies for evaluating olfactory pollution allows for the determination of odour quality of air in 'quantitative' manner. A

\section{REFERENCES AND LEGAL ACTS}

NICELL J. 2009. Assessment and regulation of odour impacts. Atmospheric Environment 43: 196-206.

PN-EN 13725: 2007 Air quality. Determination of odour concentration by dynamic olfactometry, 2007.

RUTKOWSKI J., KOŚMIDER J., SZKLARCZYK M. 1995. Odor substances in the environment, the State Inspectorate for Environmental Protection, Warsaw.

SÓWKA I. ZWOŹDZIAK J., SZKLARCZYK M., NYCH A., SKRĘTOWICZ M. 2010. Characteristics of selected methods of field studies used in the assessment of fragrance air quality around industrial facilities, [in] The contemporary problems of odour, ed. SZYNKOWSKA M., ZWOŹDZIAK J. Present Odours Issues, Scientific and Technical Publishers (WNT), Warsaw.

SÓWKA I. 2011. Methods of identification of odorous gases emitted from industrial facilities, Scientific Papers of the specific type odour is characterized with respect to its frequency and influence in a given geographical area. The tool that can be used for analysing and visualizing the spatial distribution of odours occurring in a given area using the measurement data is kriging geostatistical interpolation technique.

The application of grid and in-plume measurements and geostatistical analysis methods for evaluating odour pollution of air may be a significant tool for identifying the spatial distributions of intensity and odour type, and the effective range of odour plume from the studied odour nuisance origins.

Institute of Environmental Engineering Wroclaw University of Technology 90 Series: Monographs 55, University of Technology Press, Wroclaw.

SÓWKA I., KOWALSKI Z., SKRĘTOWICZ M., MAKARA A., SOBCZYNSKI P., STOKŁOSA K. 2013. Use of field inspections and inverse distance weighted method to assess the odor impact of a selected pig farm, Chemical Industry 6 : 1169-1172.

THE DRAFT: Law on the prevention of odor nuisance, 2009. VANCE E. 2008. What is that smell? Nature, 455: 726-728.

VDI 3882 Part 2. Olfactometry - Determination of hedonic odour tone, (Verein Deutscher Ingenieure, Berlin, 1996).

VDI3883, Part 1. Effects and assessment of odours. Psychometric assessment of odour annoyance, Questionnaires, (Verein Deutscher Ingenieure, Berlin, Beuth Verlag, 1997). 
VDI 3940 Part 1 Measurement of odour impact by field inspections - Measurement of the impact frequency of recognizable odours- Grid measurement, (Verein Deutscher Ingenieure, Berlin, 2006).

VDI 3940 Part 2 Measurement of odour impact by field inspections - Measurement of the impact frequency of recognizable odours- Plume measurement, (Verein Deutscher Ingenieure, Berlin, 2006).

VDI 3940 Part 3 Measurement of odour in ambient air by field inspections - Determination of odour intensity and hedonic odour tone, (Verein Deutscher Ingenieure, Berlin, 2008.)

WERNER P. 2004. Introduction to geo-information systems, University of Warsaw, Second Edition, expanded and updated, Warsaw.

ZWOŹDZIAK J., OBORSKA-KUMASZYŃSKA D., PATER K. 2006. Evaluation of the impact of environmental quality on health of people on the basis of multi-criteria models of statistical analysis, Environmental Medicine 1: 27-37. 